\title{
Meyer Zoysiagrass Regrowth from Sod Debris as Influenced by Herbicides
}

\author{
P.H. Dernoeden ${ }^{1}$ and M.J. Carroll ${ }^{2}$ \\ Department of Agronomy, University of Maryland, College Park, \\ MD 20742
}

\begin{abstract}
Additional index words. Mollugo verticillata, Veronica arvensis, Digitaria ischaemum, carpetweed, corn speedwell, smooth crabgrass, sod production
\end{abstract}

\begin{abstract}
In this field study, five preemergence and two postemergence herbicides were evaluated for their ability to hasten Meyer zoysiagrass (Zoysia japonica Steud.) sod development when sod was established from the regrowth of rhizomes, sod strips, and loosened plant debris. Herbicide influence on zoysiagrass re-establishment was examined using two postharvest field preparation procedures as follows: area I was raked to remove most above-ground sod debris, whereas in adjacent area II sod debris was allowed to remain in place. Herbicides that controlled smooth crabgrass [Digitaria ischaemum (Schreb.) Muhl.] generally enhanced zoysiagrass cover by reducing weed competition. Meyer established from rhizomes, sod strips, and loosened plant debris, and treated with herbicides, had a rate of sod formation equivalent to that expected in conventionally tilled, planted, and irrigated Meyer sod fields. Effective smooth crabgrass control was achieved when the rates of most preemergence herbicides were reduced in the 2nd year. Chemical names used: dimethyl 2,3,5,6-tetrachloro-1,4-benzenedicarboxylate (DCPA); 3,5,-pyridinedicarbothioic acid, 2-[difluromethyl]-4-[2-methyl-propyl]-6-(trifluoromethyl) S,S-dimethyl ester (dithiopyr); [ \pm ]-ethyl 2-[4-[(6-chloro-2benzoxazolyl)oxy]phenoxy] propanoate (fenoxaprop); 3-[2,4-dichloro-5-(1-methylethoxy)phenyl]-5-(1,1-dimethylethyl)-1,3,4-oxadiazol-2-(3H)-one (oxadiazon); $\quad \mathrm{N}$-[1ethylpropyl)-3,4-dimethyl-2,6-dinitrobenzenamine(pendimethalin); $\mathrm{N}^{3}, \mathrm{~N}^{3}$-di-n-propyl-2,4dinitro-6-[trifluromethyl)-m-phenylenediamine (prodiamine); and 3,7-dichloro-8-quinolinecarboxylic acid (quinclorac).
\end{abstract}

A major drawback associated with Meyer zoysiagrass sod production is the extended period required to produce a mature stand. Depending on plant spacing, establishment of Meyer from vegetative plugs generally requires two to three growing seasons. Establishment from sprigs requires less than two growing seasons in Maryland. Sod producers in the mid-Atlantic region normally re-establish harvested sod by tilling fields and planting vegetative sprigs or plugs. This method is similar to that used in California (Cockerham, 1988). Use of sprigs, and to a lesser extent vegetative plugs, requires access to water and irrigation equipment. An alternative approach is to re-establish sod from sod strips called ribbons, sod debris, and rhizomes that remain after harvest. Cultural practices that may enhance zoysiagrass establishment when using sod ribbons have not been investigated. Previous studies have shown that establishment of zoysiagrass from vegetative plugs can be hastened by herbicides that reduce annual grass weed com-

Received for publication 15 Oct. 1991. Accepted for publication 11 Mar. 1992. Scientific Article no. A 6132 and Contribution no. 8297 of the Maryland Agr. Expt. Sta., College Park, MD 20742. The cost of publishing this paper was defrayed in part by the payment of page charges. Under postal regulations, this paper therefore must be hereby marked advertisement solely to indicate this fact.

'Professor.

Assistant Professor. petition (Fry et al., 1986; Smith and Callahan, 1968). Herbicide safety to the crop, however, may be more important than weed control during zoysiagrass establishment (Smith and Callahan, 1968).

Objectives of this study were to determine if herbicide applications would hasten the development of Meyer zoysiagrass established from regrowth of rhizomes, sod ribbons, and debris, and to evaluate the potential phytotoxicity of new herbicides applied to evaluated using two contrasting sod ribbon and plant debris field preparation procedures.

Meyer zoysiagrass was established from plugs at the Univ. of Maryland Turfgrass Research and Education Facility in Silver Spring in 1983, and the mature stand was harvested in Aug. 1988. On 10 Apr. 1989, the area was rototilled to a depth of 2.5 to $5.0 \mathrm{~cm}$ and soil and plant debris were uniformly redistributed with a tractor mounted rake. The site was separated into two areas. Area I was hand raked to remove all loosened zoysiagrass sod debris. Area II was not raked and sod ribbons and debris were allowed to remain in place. Remaining sod ribbons ranged from 3 to $5 \mathrm{~cm}$ wide. Hence, areas I and II were adjacent, yet different locations with no statistical comparison between postharvest preparation methods being possible. About $4 \%$ to $6 \%$ of area I contained rooted sod ribbons, whereas $15 \%$ to $20 \%$ of area II was covered with zoysiagrass Meyer zoysiagrass. The two objectives were debris or rooted sod ribbons. Both areas were rolled, and herbicide treatments were applied over primarily bare ground in area I and bare ground plus loosened zoysiagrass debris and rooted ribbons in area II.

The herbicides evaluated were DCPA, dithiopyr, oxadiazon, pendimethalin, prodiamine, and quinclorac. Fenoxaprop and quinclorac were applied postemergence; the other herbicides were applied preemergence. Herbicide treatments were applied at the rates and dates shown in Tables 1 and 2 in 467 liters of water/ha at $262 \mathrm{kPa}$. The same herbicides were applied to the same plots in both years. The rates of all herbicides, except DCPA, were reduced in the 2 nd year to determine if lower rates would be effective in controlling smooth crabgrass while zoysiagrass cover increased. CDPA rate was not reduced because previous Maryland studies showed that rates $\leq 11.76 \mathrm{~kg} \cdot \mathrm{ha}^{-1}$ provided erratic levels of smooth crabgrass control (Demoeden, 1984). Quinclorac was tankmixed with 2.3 liters of a nonionic surfac$\operatorname{tant} /$ ha. Both sites were irrigated or received from rainfall 30 to $40 \mathrm{~mm}$ of water within $24 \mathrm{~h}$ of herbicide application. Otherwise, the sites were not irrigated in 1989 or 1990 . In 1989 , there was $1260 \mathrm{~mm}$ of rain, and between $1 \mathrm{Jan}$. and the last rating date of 9 Oct. 1990, there was $890 \mathrm{~mm}$ of rain. Nitrogen from urea was applied at $49 \mathrm{~kg} \mathrm{~N} / \mathrm{ha}$ on 20 July 1989, and 15 May, 13 June, 10 July, and 20 Aug. 1990. Plots were mowed monthly to a height of 4 to $5 \mathrm{~cm}$ in 1989 , but were mowed every 14 to 21 days at 3 to $4 \mathrm{~cm}$ from mid-May to Oct. 1990.

Plots were $1.5 \times 3.0 \mathrm{~m}$ and were arranged in a randomized complete block with four replicates of each herbicide. Soil was a Sassafras sandy loam (fine loamy, siliceous, mesic Typic Hapludult) with a $\mathrm{pH}$ of 6.9 and $10 \mathrm{mg}$ organic matter per gram soil. Plot area covered by weeds or zoysiagrass was determined visually on a $0 \%$ to $100 \%$ linear scale where $0=$ no weeds or zoysiagrass and 100 $=$ entire plot area covered. An excellent level of weed control was judged to be $<5 \%$ smooth crabgrass or broadleaf weed cover in herbicide-treated plots. All data were subjected to analyses of variance and means were separated at $P=0.05$ by Duncan's multiple range test.

Carpetweed (Mollugo verticillata L.) and smooth crabgrass were the primary weed competitors in 1989. In area I, carpetweed was effectively controlled by all preemergence herbicides, but not by fenoxaprop or quinclorac (Table 1). By 13 Sept., smooth crabgrass had been reduced significantly by all treatments relative to the control. Except for pendimethalin and prodiamine, most herbicides contributed to improved zoysiagrass cover $(24 \%$ to $34 \%)$ when compared with untreated plots $(13 \%)$ where zoysiagrass had to compete with smooth crabgrass.

In area II, only pendimethalin, prodiamine, and oxadiazon controlled carpetweed, whereas all herbicides provided excellent smooth crabgrass control (Table 1). Data collected 17 July suggested that herbicide use did not affect zoysiagrass cover. 
Table 1. Weed and Meyer zoysiagrass cover as influenced by postharvest preparation treatment and herbicides 1989.

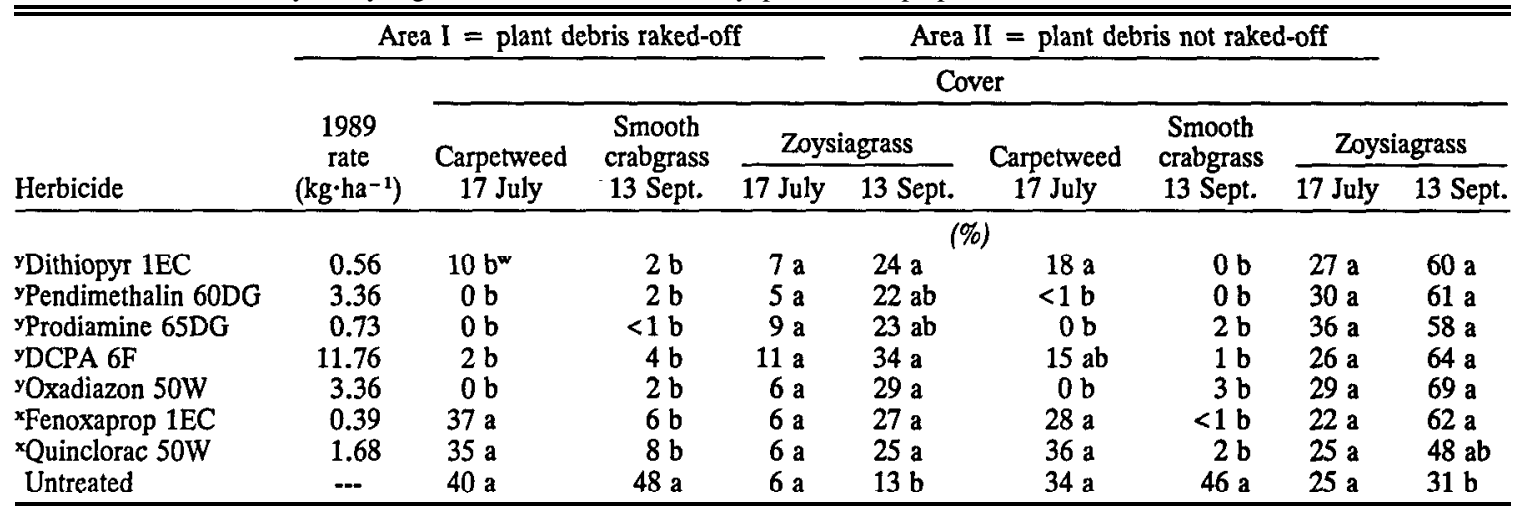

${ }^{2}$ Sod was harvested in Aug. 1988 and there was no regrowth in 1988 from rhizomes. On 10 Apr. 1989, the area was rototilled. On

19 Apr. 1989, area I was raked to remove all loosened zoysiagrass debris, whereas in area II plant debris was allowed to remain in place.

${ }^{y}$ Preemergence herbicides were applied on 19 Apr. 1989.

${ }^{x}$ Herbicides were applied postemergence on 7 July 1989, when smooth crabgrass plants averaged $>8$ tillers per plant.

"Mean separation in columns by Duncan's multiple range test at $P=0.05$.

Table 2. Weed and Meyer zoysiagrass cover as influenced by postharvest preparation treatment and herbicides $1990{ }^{2}$

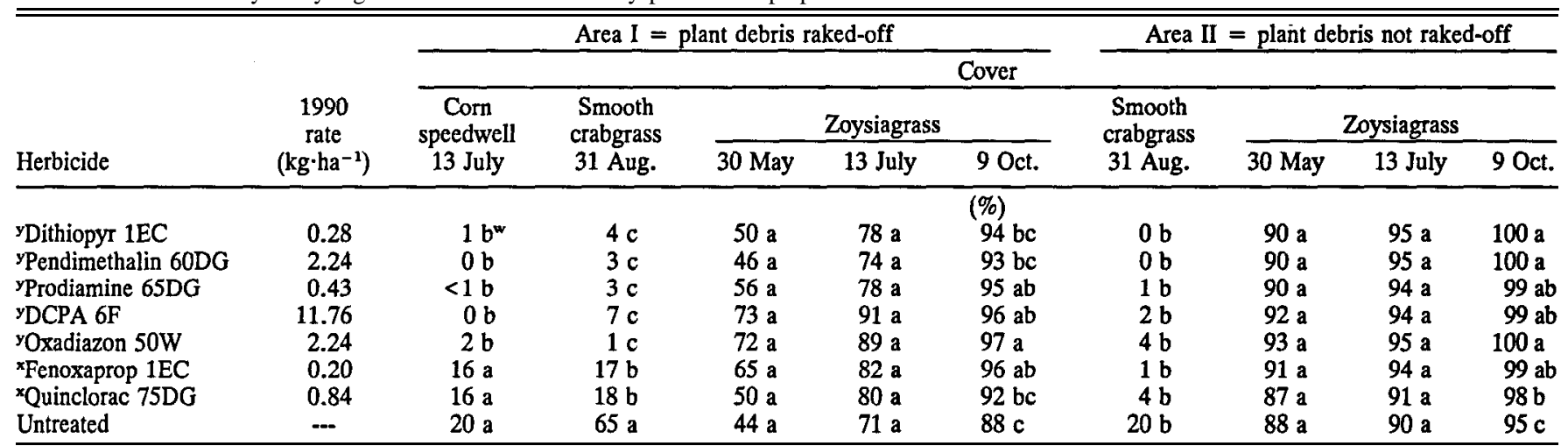

${ }^{2}$ Sod was harvested in Aug. 1988 and there was no regrowth in 1988 from rhizomes. On 10 Apr. 1989, the area was rototilled. On 19 Apr. 1989, area I was raked to remove all loosened zoysiagrass debris, whereas in area II plant debris was allowed to remain in place.

"Preemergence herbicides were applied 1 Apr. 1990.

"Herbicides were applied postemergence when smooth crabgrass was four-leaf to four-tiller stage on 25 June 1990.

"Mean separation in columns by Duncan's multiple range test at $P=0.05$.

By 13 Sept., however, all herbicide-treated plots, except quinclorac, had about twice the zoysiagrass cover as untreated plots.

Between 13 Sept. 1989 (Table 1) and 30 May 1990 (Table 2), zoysiagrass cover increased rapidly, which was attributed to a relatively warm and moist fall and spring. Corn speedwell (Veronica arvensis L.) colonized area I primarily during late Spring 1990, following preemergence herbicide ap plication. All preemergence herbicides applied on 1 Apr. effectively controlled corn speedwell, but not fenoxaprop or quinclorac.

Although rates of all herbicides, except DCPA, were reduced in 1990, all preemergence herbicides provided excellent smooth crabgrass control in area I (Table 2). Fenoxaprop and quinclorac controlled smooth crabgrass, but only $73 \%$ control was achieved relative to untreated plots. Herbicide use in area I was associated with more extensive zoysiagrass cover, but these increases did not vary significantly from untreated plots on 30 May or 13 July. By 9 Oct., however, zoysiagrass cover was significantly better in plots treated with oxadiazon, prodiamine, DCPA, and fenoxaprop, than in untreated plots.

In area II, all herbicides provided excellent smooth crabgrass control because zoysiagrass cover was very high through Spring 1990 and weed competition was, therefore, not as severe as it was in area I. While herbicide treatments assisted zoysiagrass establishment in 1990, the benefits of herbicide use were not as great as in 1989 .

In area II, where debris was left after harvesting, the surface was conspicuously uneven during 1989. By Fall 1990, however, the surface had become smooth and uniform. Although the two postharvest preparation treatments were not replicated, the data for zoysiagrass cover indicate that sod debris distributed and allowed to remain on-site will assist in hastening zoysiagrass regrowth, when compared with removing all loosened plant debris from the field.

Herbicides significantly reduced weed competition and thereby enhanced zoysiagrass cover in area I and II in 1989 and again in 1990 when rates of most herbicides were reduced. Zoysiagrass coverage in area II at the end of the study was equivalent to the coverage that would be expected in fields established using conventional tilling, sprigging, weed control, and irrigation methods. None of the herbicides was associated with a reduction in the growth of Meyer zoysiagrass. Further, a reduction in preemergence herbicide rates achieved effective smooth crabgrass control, as zoysiagrass cover had increased in the 2 nd year.

\section{Literature Cited}

Cockerham, S.T. 1988. Turforass sod production. Coop. Ext. Publ. 21451. Div. of Agr. and Natl. Resources. Univ. of California, Oakland.

Demoeden, P.H. 1984. Management of preemergence herbicides for crabgrass control in transition zone turf. HortScience 19:443-445.

Fry, J.D., P.H. Demoeden, and J.J. Murray. 1986 Establishment and rooting of zoysiagrass (Zoysia japonica) as affected by preemergence herbicides. Weed Sci. 34:413-418.

Smith, G.C. and L.M. Callahan. 1968. Herbicidal phytotoxicity to Emerald zoysia during establishment. Weed Sci. 163312-315. 